\title{
Vertical Distribution of Scab in Large Pecan Trees
}

\author{
Clive H. Bock, Ted E. Cottrell, Mike W. Hotchkiss, and Bruce W. Wood, USDA-ARS-SEFTNRL, 21 Dunbar Road, Byron, GA \\ 31008, USA
}

Abstract

Bock, C. H., Cottrell, T. E., Hotchkiss, M. W., and Wood, B. W. 2013.Vertical distribution of scab in large pecan trees. Plant Dis. 97:626-634.

\begin{abstract}
Pecan scab (Fusicladium effusum) is a destructive disease of pecan in the southeastern United States. This study was conducted to investigate the vertical distribution of scab in tall pecan trees (14 to $16 \mathrm{~m}$ tall) in three experiments in 2010 and 2011. Although 2010 had average rainfall, a factor that drives scab epidemics, 2011 was a very dry year with a consequently low scab severity. A total of eight trees were included in each experiment, four were nontreated controls, and four were sprayed using a ground-based air-blast sprayer. Trees were assessed for foliar and fruit scab at $0-5.0,5.0^{+}-7.5,7.5^{+}-10.0,10.0^{+}-12.5$, and $12.5^{+}-$ $15.0 \mathrm{~m}$. Mixed model analysis showed main effects of height, fungicide treatment, and height*treatment interactions in all three experiments, although on foliage the effects were less consistent $(P$ value $=$ $0.003-0.8$ ), perhaps due to delayed fungicide applications early in the season. However, fruit of nontreated trees had more severe scab low in the canopy compared to fungicide-treated trees, with a consistent height*treatment interaction $(P$ value $=<0.0001-0.04)$. Most often the severity of scab in the upper canopy was similar in trees on fungicide-
\end{abstract}

treated and nontreated trees, suggesting that fungicide had less impact at heights $\geq 10.0 \mathrm{~m}$ compared to $<10.0 \mathrm{~m}$ in the canopy. There was a consistent reduction in scab severity on foliage and on immature fruit in August due to fungicide treatment at heights $\leq 10.0 \mathrm{~m}$. Above 10.0 $\mathrm{m}$, the effect was inconsistent, but late in the season (October), the fungicide-treated trees showed lower scab severity throughout the canopy. A metallic tracer study using cerium $(\mathrm{Ce})$ showed an exponential relationship between quantities of $\mathrm{Ce}$ recovered and sample height in the canopy, with the quantity of $\mathrm{Ce}$ at $\geq 10 \mathrm{~m}$ being statistically equal to background levels. The relationship between scab severity on fruit and sample height in the canopy of nontreated trees was most often described by a negative linear function, but there was no discernible relationship on fungicide-treated trees, as the severity of scab in the lower canopy was most often similar to that in the upper canopy. Gradients in fungicide coverage and scab severity have ramifications for scab management options and potentially for the development of fungicide resistance in F. effusum.
Pecan scab (caused by Fusicladium effusum G. Winter) is a widespread and destructive disease of pecan (Carya illinoinensis Koch.) in the southeastern United States and other relatively wet locations (e.g., eastern South Africa, southern Brazil, northeastern Mexico) where pecan is grown (2). Infection with pecan scab results in yield loss caused by premature fruit drop $(7,8,16,22)$, and also through reduction in quality of harvested fruit $(7,16,22)$.

The pathogen is spread primarily through air- and splash-borne conidia $(4,6,7,12)$. The quantity of conidia produced increases during the season as the epidemic develops and when conditions are favorable for repeated cycles of dispersal and infection (6). After rainfall, conidia are dispersed in air currents, with localized dispersal occurring through splash $(6,12)$. Subsequent to dispersal, periods with temperatures of 15 to $25^{\circ} \mathrm{C}$ and leaf wetness of 24 to $48 \mathrm{~h}$ are conducive for infection $(5,25)$. Related species of Fusicladium are also dispersed in both wind and rain, with splash playing a major role $(10,17)$. The polycyclic nature of pecan scab and the period over which leaves and fruit remain susceptible $(5,11,25)$ makes it a major threat, as cycles of infection can result in a rapid build-up of inoculum and subsequent disease $(11,22)$. The degree to which these epidemiological processes might affect patterns of disease distribution on fruit and foliage in the canopy has not been considered, but has important ramifications for scab management.

When environmental conditions are conducive, scab may increase on fruit until harvest $(7,22)$, although later infections have less effect on fruit yield and quality (22). There are various fungicides used for controlling scab on pecan $(1,8,18)$, but there are

Corresponding author: C. H. Bock, E-mail: clive.bock@ars.usda.gov

Accepted for publication 3 December 2012.

http://dx.doi.org/10.1094/PDIS-05-12-0453-RE

This article is in the public domain and not copyrightable. It may be freely reprinted with customary crediting of the source. The American Phytopathological Society, 2013. risks of fungicide resistance $(9,15,18,21,23)$. Managing scab in a tall tree crop like pecan, which can grow to $15+\mathrm{m}$, presents major challenges to achieving sufficient spray coverage to ensure good scab control $(13,24)$. Uniform fungicide coverage will not only improve scab control, but will also reduce the risk of fungicide resistance developing in the pathogen that might otherwise be exposed to reduced concentrations of active ingredient. Studies on pecan have shown that ground-based spray coverage diminishes as tree height increases $(13,24)$, and coverage from aerial applications diminishes with increasing distance from the tree apex (13). Observations show that over-wintering shoots of both sprayed and unsprayed trees had more lesions per meter in the top third of the trees compared to the middle or lower third (14); and Reilly et al. (13) described early leaf drop in the upper third of tall pecan trees being attributed to pathogens and pests, and suggested poor canopy coverage from ground-based sprayers resulting in increased pest and disease causing the defoliation. These observations indicate a gradient of more severe disease higher in the canopy of pecan trees, but this has not been confirmed on foliage or fruit with disease or pest data.

Knowledge of the distribution of scab in tree canopies is important for a number of reasons: the pattern can help provide information on epidemiological processes and factors involved in infection including sources of inoculum, dissemination, and reproductive strategies $(3,20)$; and it can help guide management strategies to control the disease (13). Furthermore, a preliminary understanding of scab distribution within the pecan tree canopy in untreated and fungicide-treated trees is useful, as it provides a basis for contrasting effects of spray coverage on scab control and distribution within the canopy (14). Mature pecan trees are substantially taller $(>15 \mathrm{~m})$ than most other tree species in which disease distribution has been studied $(3,20)$. There is no information on the distribution of scab on foliage or developing fruit within pecan tree canopies during a scab epidemic. Once scab distribution in the canopy is characterized, it can be studied in relation to various spray regimes, thus facilitating development of improved recommendations for effective disease control. 
Sprays for disease control can be more effectively targeted if applied where most disease is likely to occur. An assessment of scab on individual tree organs (e.g., leaflets and fruit) at different heights within the canopy will provide data required for characterizing disease distribution in relation to height and treatment, thereby forming the basis for more effective exploration of the effects of different scab management approaches (different ground spraying and/or aerial application strategies). The objectives of this study were to characterize scab distribution in canopies of scabsusceptible pecan trees, and to assess effects of fungicide applications on scab severity with height in the canopy.

\section{Materials and Methods}

Pecan orchards and experiment design. The experiment was conducted twice on 14 to $16 \mathrm{~m}, \sim 30$-year-old pecan trees of cv. Desirable, and once on trees of $\mathrm{cv}$. Wichita at the USDA-ARS research farm in Byron, GA (located at latitude $32.652^{\circ} \mathrm{N}$, longitude $83.739^{\circ} \mathrm{W}$, elevation $156 \mathrm{~m}, 240$ days freeze-free growing period, annual precipitation of $118 \mathrm{~cm}$ ). Trees of 14 to $16 \mathrm{~m}$ (or taller) are typical of many pecan orchards within the southeastern United States. The same factorial design (fungicide treatment [2] $\times$ height [5]) was used in all three experiments. In both 2010 and 2011, eight trees of cv. Desirable were arbitrarily chosen within a mixed block of cultivars. Trees had received five applications of fungicide (Super Tin 4L [triphenyltin hydroxide] at 0.9 liter ha ${ }^{-1}$

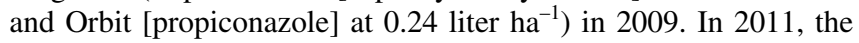
experiment was repeated in a block of cv. Wichita trees, which in 2010 were either unsprayed or received applications of Prophyte

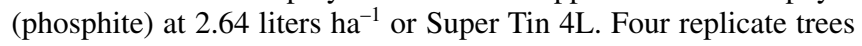
in each experiment received no fungicide treatment, and four replicate trees were treated with fungicide. Trees were randomly allocated to treatments. In 2010, the four fungicide-treated trees of cv. Desirable received six spray applications, comprising four sprays of Orbit at approximately biweekly intervals between 16 April and 7 June, followed by two applications of Super Tin 4L on 29 June and 23 July. In 2011, both Desirable and Wichita received seven applications of Super Tin 4L at approximately 2- to 3-week intervals, from 27 April to 9 August.

All spray applications were made using a ground-based axle-fan turbine air-blast sprayer (Aerofan D2/40 1000, Reedley, CA). Sprayer application speed was $2 \mathrm{mph}$ with an application rate of 940 liters ha ${ }^{-1}$ at $1.03 \times 10^{6}$ Pascal. A 3-25 disc and core sprayer nozzle (TeeJet Nozzles, Spraying Systems Co., Wheaton, IL) was used in the three rows of sprayers in the four lower positions of the sprayer manifold, and a 4-25 combination for the upper five nozzle rows of the manifold.

Rainfall data for the location was obtained from the Georgia Automated Environmental Monitoring Network (http://www.griffin. uga.edu/aemn/). For the crop growing period in 2010 and 2011, data were downloaded for the USDA-ARS research farm weather station, and data for the long-term climate averages (54-year averages) were downloaded for the Macon Middle GA Regional Airport, Bibb County, GA (32.683 ${ }^{\circ} \mathrm{N}, 83.650^{\circ} \mathrm{W}$, elevation $\left.105 \mathrm{~m}\right)$.

Disease assessments. In 2010, each tree of cv. Desirable was assessed for scab severity by taking two vertical transects up the canopy and collecting samples at the midpoints of each of the five sample heights $\left(0.0-5.0,5.0^{+}-7.5,7.5^{+}-10.0,10.0^{+}-12.5\right.$, and $12.5^{+}$$15.0 \mathrm{~m}$ ) using a hydraulic boom lift (JLG Industries Inc., McConnelsburg, PA). Leaves or fruit within approximately $1 \mathrm{~m}$ of the sample height location were collected arbitrarily. Heights aboveground were measured using an Opti-Logic Laser Rangefinder (Opti-Logic, Tullahoma, TN). In 2011, samples of Desirable and Wichita were taken along a single vertical transect. In 2010, a scab assessment was made on foliage on 19 July, and two scab assessments were made on the fruit on 12 August and 21 October. In the 2011 experiment, scab assessments of Desirable foliage were taken on 14 June, and on fruit on 4 August and 11 October. Scab assessments of Wichita foliage were taken on 2 June, and on fruit on 2 August and 14 October. In 2010, 10 leaves and five fruit were arbitrarily sampled from each height in each transect, and in
2011, 10 leaves and 10 fruit were collected from each height. The percent area infected was visually assessed on each leaflet of each compound leaf. Scab on fruit was assessed similarly. Pecan fruit are comprised of four valves joined along their edges by a suture, and each of the four valve faces was assessed individually (26).

Tracer study of ground-based spray distribution. In 2010, two trees were also sprayed with a cerium (Ce) tracer at molar concentration equivalent to the recommended rate of the active ingredient propiconazole (0.39 millimolar) using the air-blast sprayer. The sprays were applied to both sides of the trees, and samples were taken from four replicate transects on either side of the trees as described for the samples taken for disease assessments in the previous section. Samples were taken immediately after the foliage had dried using a Birkestrand leaf disc punch (Rabbit Tool USA, Inc., Rock Island, IL), obtaining ten $2.54 \mathrm{~cm}^{2}$ leaf discs at each height in each transect. The discs were bulked and immediately washed in $2 \%$ nitric acid $\left(\mathrm{HNO}_{3}\right)$ for $2 \mathrm{~min}$, and removed from the vial. After washing in nitric acid, concentrations of $\mathrm{Ce}$ were determined by ICP-MS (Inductively Coupled Plasma Quadrapole Mass Spectrometry; PerkinElmer SCIEX ELAN-9000; Concord, Ontario, CA). Quantitative analysis was facilitated by a similar-mass internal standard $\left(\mathrm{Ge}^{72}\right)$, and by external standards using multi-element standard solutions (PerkinElmer Multi-element Calibration Standard Sets) diluted to span three to four orders of concentration magnitude so as to quantify the spray deposited from the air-blast sprayer in the tree canopy at different heights. Equivalent samples of leaf material were similarly taken from nontreated trees to test background Ce levels.

Data analysis. SAS v9.3 (SAS Institute, Inc., Cary, NC) was used in all data analyses. To determine if there were any differences between fungicide treatments or at different canopy heights, generalized linear mixed models (PROC GLIMMIX) were used to analyze the data from all three factorial experiments and the tracer experiment. Two fixed-effect factor models were used, where the dependent variable (scab severity) was $Y_{i j k}=\theta+\alpha_{i}+\beta_{j}+(\alpha \beta)_{i j}+$ $e_{i j k}$, where $\theta$ is a constant (the intercept term), $\alpha_{i}$ is the main effect of fungicide treatment, $\beta_{j}$ is the main effect of height, $(\alpha \beta)_{i j}$ is the interaction term, and $e_{i j k}$ the residual error. To explore the effects of fungicide treatment*height interactions, least-square means were calculated, and the "slice" statement was used to analyze treatment effects at each of the five sample heights, and differences in scab severity among sample heights at each of the two levels of treatment. Residuals, residual distributions, and quantile plots of these data were analyzed to ascertain that assumptions of normality and homogeneity of variance were not violated. Pairwise differences for the fungicide treatment*height lsmeans sliced by fungicide treatment or height were explored using the "lines" option of the "slice" statement which display letters indicating means separation based on a t-grouping. In addition, $95 \%$ confidence intervals were calculated. A linear regression function (PROC REG, $y=a+b x$, where $a=$ intercept, $b=$ slope) was fit to explore the relationship between scab severity on leaflets and fruit on each assessment date and height in nontreated and fungicide-treated trees. Nonlinear regression (PROC NLIN) applying an exponential function $\left(\mathrm{Y}=\mathrm{e}^{\mathrm{a}-\mathrm{bX}}\right)$ was used to explore the relationship between sample height and spray deposition ( $F$ and $P$ values, and the coefficient of determination $\left[R^{2}\right]$ were used to evaluate the goodness-of-fit for both linear and nonlinear regression).

\section{Results}

Scab was most severe on Desirable in 2010 and least on both Desirable and Wichita in 2011, although Wichita was more severely scabbed than Desirable in 2011 (Fig. 1). Scab severity was lowest early in the season on foliage for both nontreated and fungicide-treated trees, but increased on fruit in all three experiments. Rainfall was below average and less well distributed in 2011; spring and early summer were particularly dry with a total of 591 $\mathrm{mm}$ falling during the experimental period (Fig. 2) compared to $766 \mathrm{~mm}$ for the same period in 2010, and $739 \mathrm{~mm}$ for the 54-year average. Rainfall plays a critical role in scab epidemics 
$(4,6,7,12,19)$, so it is not surprising that 2011 was a very mild epidemic year. The first fungicide application was made after the first leaves were expanding in both seasons.

The spray coverage distribution based on the samples of a Ce tracer demonstrated that although deposition was substantial at $\leq 5$ $\mathrm{m}$ height (mean maximum 1.2 picomoles $\mathrm{cm}^{-2}$ leaf), there was significantly less active ingredient sprayed to heights $>7.5 \mathrm{~m}$ (Fig. $3 \mathrm{~A})$. At $\geq 10 \mathrm{~m}$ height, the quantity sampled on treated trees was not significantly different from the background levels found on

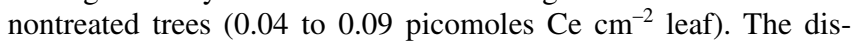
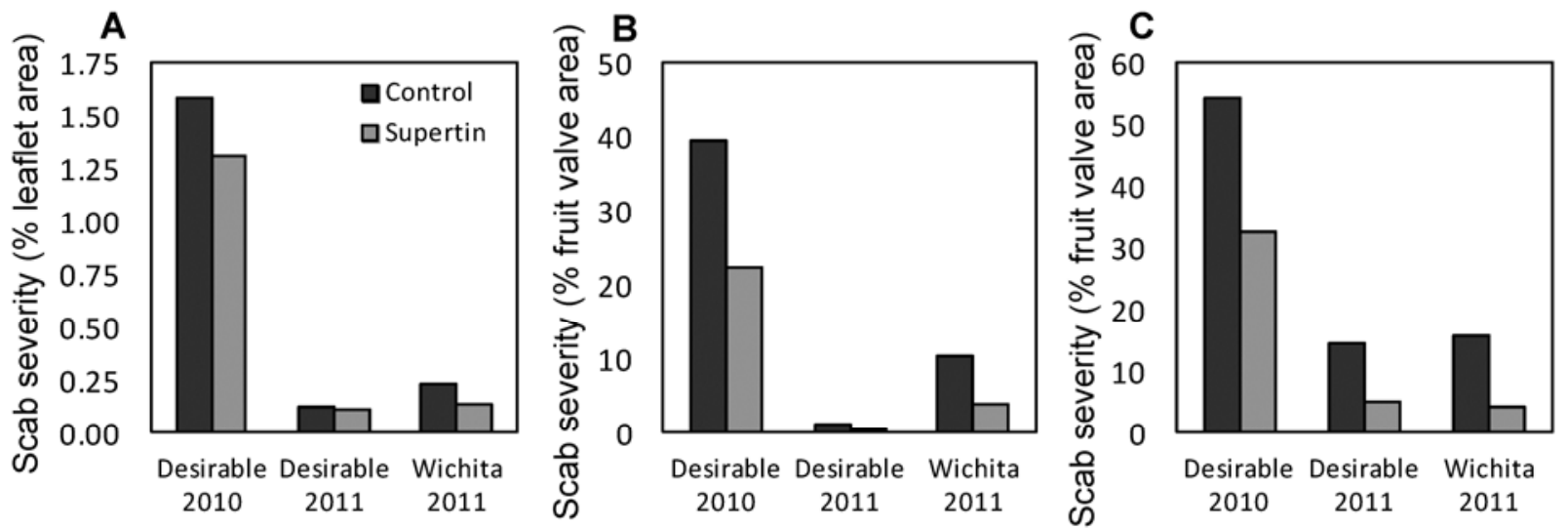

Fig. 1. Mean severity of pecan scab (caused by Fusicladium effusum) on A, leaflets in June, and fruit valves in B, August and C, October on nontreated control pecan trees and trees receiving fungicide applications using an air-blast sprayer in Byron, GA.

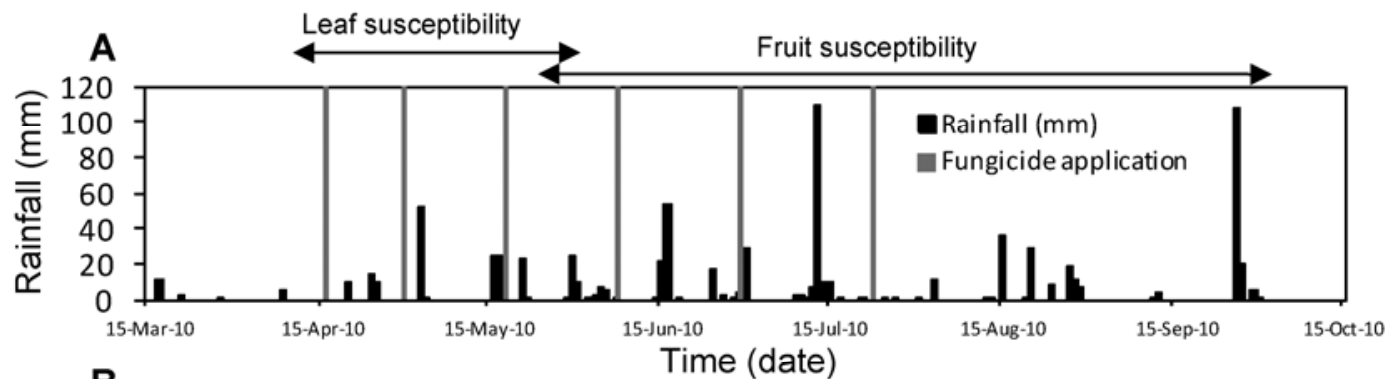

B

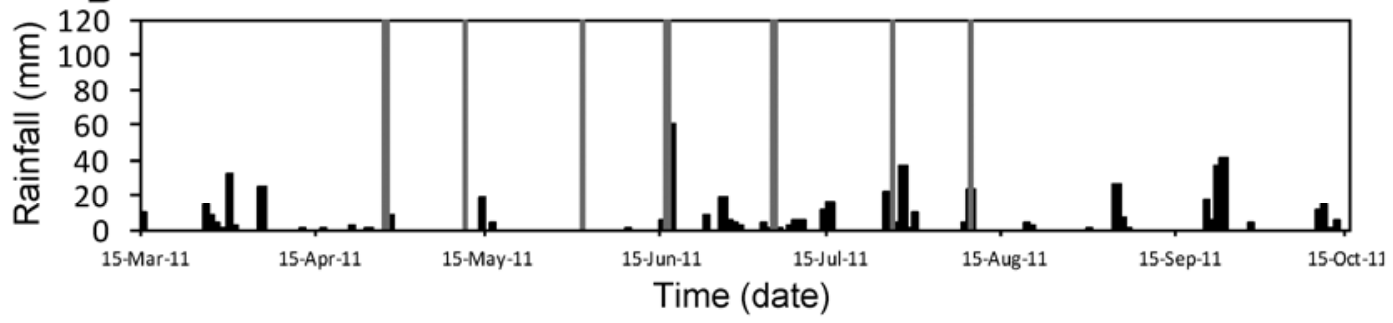

Fig. 2. Weather conditions (rainfall, $\mathrm{mm}$ ) and fungicide application dates in relation to approximate foliar and fruit susceptibility periods $\mathbf{A}$, on $\mathrm{cv}$. Desirable in 2010 , and $\mathbf{B}$, on cvs. Desirable and Wichita in 2011 in Byron, GA.
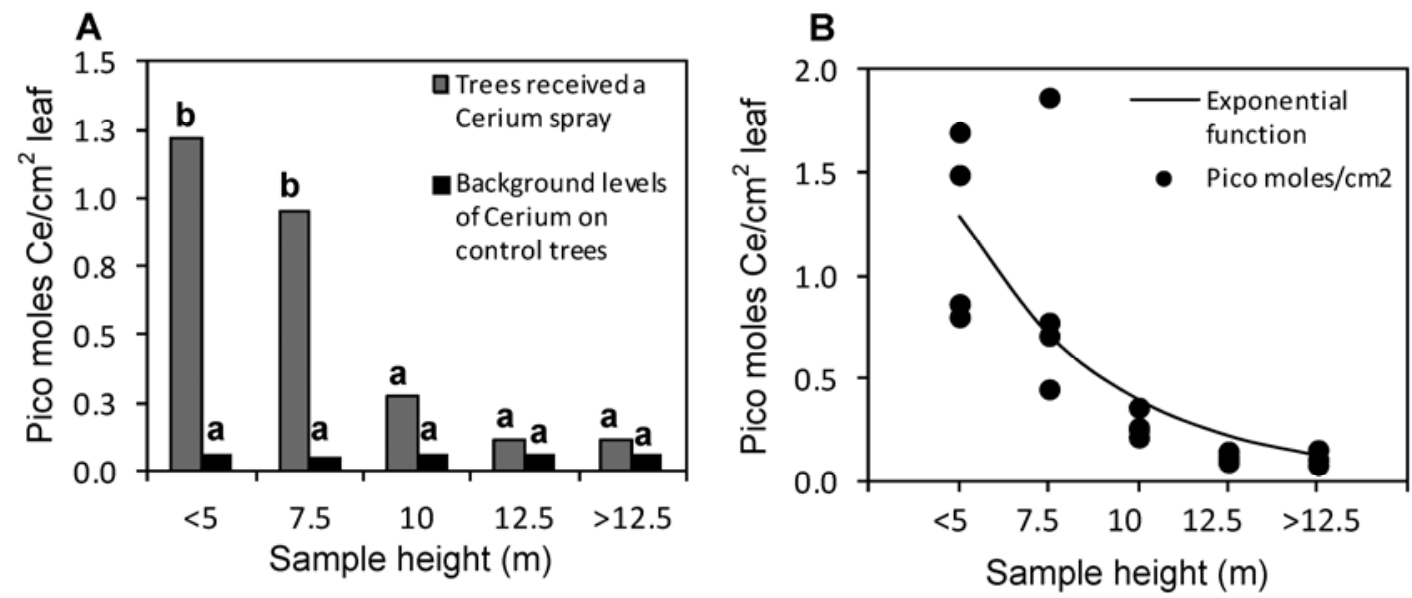

Fig. 3. Air-blast spray coverage in pecan trees demonstrating $\mathbf{A}$, differences in molar equivalence of active ingredient (measured using a cerium [Ce] tracer) on leaflets on $\mathrm{cv}$. Desirable at different heights, and B, relationship between height and molar equivalence of active ingredient collected in an experiment in 2010 in Byron, GA. If letters are different, then the treatments are significantly different according to t-grouping $(P=0.05)$. Exponential function $Y=e^{a-b X}, F$ value $=40(P<0.0001)$ where $a=0.84, b=0.59, R^{2}=0.90$. 
tribution of applied sprays followed a negative exponential relationship with height aboveground (Fig. 3B).

The two fixed-effect factor model analysis (Table 1) showed fungicide treatment*height interactions significantly affected scab severity on all sample dates except on foliage on Desirable and Wichita in 2011, when scab severity was extremely low due to drought conditions. On all other sample dates, the significance of the interaction ranged from $<0.0001-0.05$. Main effects of fungicide treatment and height were most often significant.

In relation to sample height in the canopy, the severity of scab on leaflets (mean severity per diseased leaflet) on nontreated trees was higher $\leq 7.5 \mathrm{~m}$ in the canopy in 2010 on Desirable and in 2011 on Wichita, but there was little effect on Desirable in 2011 (Fig. 4). On fungicide-treated trees there was more severe $\mathrm{scab} \geq 12.5 \mathrm{~m}$ on Desirable in 2010, no effect on Desirable in 2011, and least scab at $10.0 \mathrm{~m}$ on Wichita in 2011. In relation to treatment (Fig. 5), fungicide-treated trees had less scab at $\leq 7.5 \mathrm{~m}$ compared to nontreated trees on Desirable in 2010, but at no other time was there a difference in scab severity on leaflets between treated and nontreated trees. The rather late timing of fungicide sprays in relation to leaf development and thus potential infection, particularly in 2011, and the rather dry nature of the early season may have precluded seeing effects of height or fungicide treatment.

On immature fruit in August, there was significantly more scab lower in the canopy in nontreated trees in all three experiments (Fig. 6), while on fungicide-treated trees of Desirable in 2010, there was least scab at $\leq 5.0 \mathrm{~m}$ and $12.5 \mathrm{~m}$ compared to other heights, but there was no difference among heights on Desirable or Wichita in 2011. In comparing treatments at each height (Fig. 7), in all three experiments there was consistently more scab on fruit valves of nontreated trees $\leq 5.0 \mathrm{~m}$ aboveground, but no difference between the two treatments $\geq 12.5 \mathrm{~m}$ aboveground. In all three experiments, the trend was for significant effects of fungicide treatment lower in the canopy, but no difference at the sample heights higher in the canopy, although the exact pattern varied between years.

On mature fruit in October on fungicide-treated trees, scab severity was greatest on valves in the middle $(7.5$ to $10 \mathrm{~m})$ or base $(\leq 5 \mathrm{~m})$ of the tree in the experiment in 2010 and the two experiments in 2011, respectively (Fig. 8). There was no effect of sample height on scab severity on the fungicide-treated trees in any of the experiments. The comparison of treatments (Fig. 9) showed that there were consistent significant differences in scab severity between treated and nontreated trees at $\leq 7.5 \mathrm{~m}$ in all three experiments. On Desirable in 2010, although there was no effect at 10.0 to $12.5 \mathrm{~m}$, there was a significant effect at 7.5 to $10.0 \mathrm{~m}$ and $\geq 12.5$ m. With Wichita in 2011, there was a significant effect at all heights $\leq 12.5 \mathrm{~m}$. There was no effect of fungicide treatment at $\geq 7.5$ $\mathrm{m}$ on Desirable in 2011.

The effect of fungicide treatment on the percent reduction in scab severity ([severity on nontreated trees] - [severity on treated trees]/[severity on nontreated trees] $\times 100$ ) shows interesting trends with height and at different times within season (Fig. 10). Although effects were least in foliage, there was consistent reduction in the severity of scab at $\leq 7.5 \mathrm{~m}$ (Fig. 10A), but at heights of $\geq 10 \mathrm{~m}$, this was less consistent among seasons, with higher scab severity at $\geq 12.5 \mathrm{~m}$ on fungicide-treated trees of Wichita in 2011. On immature fruit, fungicide effects in reducing scab severity were con-

Table 1. Type $3^{\text {a }}$ tests of fixed effects for fungicide treatment, height aboveground, and the interaction of fungicide treatment*height aboveground on the severity of pecan scab (Fusicladium effusum) in the canopy of nontreated pecan trees or trees receiving fungicide applications using an air-blast sprayer

\begin{tabular}{|c|c|c|c|c|}
\hline Variable & Cultivar & $\begin{array}{c}\text { Treatment }^{\mathbf{b}} \\
F \text { value }(P>F)^{\text {c,d }}\end{array}$ & $\begin{array}{c}\text { Height } \\
F \text { value }(P>F)\end{array}$ & $\begin{array}{c}\text { Treatment*height } \\
F \text { value }(P>F)\end{array}$ \\
\hline Severity per infected leaf & $\begin{array}{l}\text { Desirable } 2010 \\
\text { Desirable } 2011 \\
\text { Wichita } 2011\end{array}$ & $\begin{array}{l}8.9(0.003) \\
1.5(0.2) \\
5.3(0.02)\end{array}$ & $\begin{array}{l}1.8(0.1) \\
0.7(0.6) \\
3.6(0.007)\end{array}$ & $\begin{array}{l}2.4(0.05) \\
0.4(0.8) \\
0.9(0.5)\end{array}$ \\
\hline $\begin{array}{l}\text { Percent fruit valve area } \\
\text { diseased (August) }\end{array}$ & $\begin{array}{l}\text { Desirable } 2010 \\
\text { Desirable } 2011 \\
\text { Wichita } 2011\end{array}$ & $\begin{array}{l}67(<0.0001) \\
22(<0.0001) \\
20(<0.0001)\end{array}$ & $\begin{array}{c}7.8(<0.0001) \\
12(<0.0001) \\
5.2(0.0004)\end{array}$ & $\begin{array}{c}14(<0.0001) \\
11(<0.0001) \\
7.0(<0.0001)\end{array}$ \\
\hline $\begin{array}{l}\text { Percent fruit valve area } \\
\text { diseased (October) }\end{array}$ & $\begin{array}{l}\text { Desirable } 2010 \\
\text { Desirable } 2011 \\
\text { Wichita } 2011\end{array}$ & $\begin{array}{l}53(<0.0001) \\
28(<0.0001) \\
56(<0.0001)\end{array}$ & $\begin{array}{l}2.3(0.06) \\
1.2(0.3) \\
7.2(<0.0001)\end{array}$ & $\begin{array}{l}2.6(0.04) \\
3.0(0.02) \\
7.0(<0.0001)\end{array}$ \\
\hline
\end{tabular}

${ }^{a}$ Data were analyzed using SAS v9.3 with PROC GLIMMIX with terms for main effects of treatment and height and for the interaction treatment*height.

${ }^{\mathrm{b}}$ Degrees of freedom: Treatment $=1$, Height $=4$, Treatment*Height $=4($ Den DF $=390)$.

${ }^{\mathrm{c}} F$ values. $P>F$ indicates the probability that the $F$ value for the treatment effect for the null hypothesis is not significant.

${ }^{\mathrm{d}}$ Fit statistics (AIC) for Desirable 2010: Severity per infected leaf $=2480$; percent leaves infected $=6665$; percent area diseased $=3531$; fruit weight $=2093$; percent area diseased $=3583$; fruit weight $=2424$. Fit statistics $($ AIC) for Desirable 2011: Severity per infected leaf $=302$; percent leaves infected $=2119$; percent area diseased $=1718$; fruit weight $=1432$; percent area diseased $=3417$; fruit weight $=2200$. Fit statistics (AIC) for Wichita 2011: Severity per infected leaf $=420$; percent leaves infected $=2621$; percent area diseased $=3237$; fruit weight $=1687$; percent area diseased $=3284$; fruit weight $=2196$.
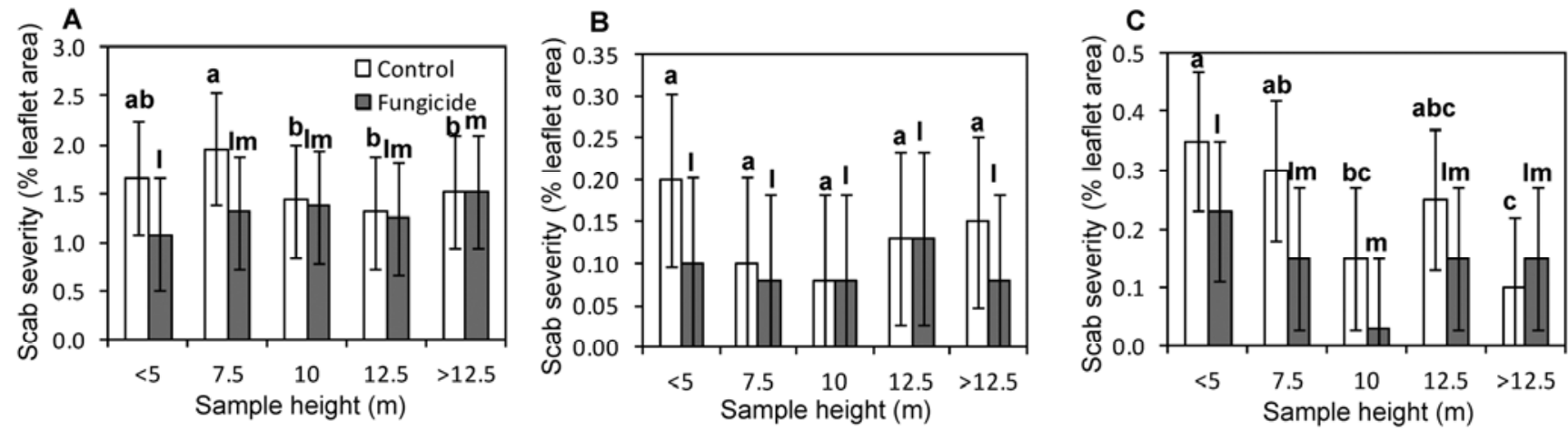

Fig. 4. Severity (\% area diseased per diseased leaflet) of pecan scab (Fusicladium effusum) on leaflets of pecan at different heights aboveground in the canopies of nontreated control trees and trees receiving fungicide applications using an air-blast sprayer. A, Cultivar Desirable, June 2010, B, cultivar Desirable, June 2011, and C, cultivar Wichita, June 2011 in Byron, GA. Data sliced by treatment (nontreated or fungicide-treated). If letters are different within treatments, then the severity of scab is significantly different between heights according to t-grouping $(P=0.05) .95 \%$ confidence intervals are indicated. 
sistent at $\leq 10.0 \mathrm{~m}$ (Fig. 10B). At $\geq 12.5 \mathrm{~m}$, the effect was inconsistent. However, on mature fruit in October, there was a discernible and consistent effect of fungicide in reducing scab at all heights and in all seasons (Fig. 10C), perhaps due to the cumulative effect of treatment on the epidemic in fungicide-treated trees compared to nontreated trees.

Linear regression analysis of the relationship between scab severity on leaflets and sample height showed very little relationship, confirming the results of the previous analysis (Table 2). Only on nontreated trees of Wichita in 2011 was there a slight negative relationship (model $F$ value probability $=0.08, R^{2}=0.70$ ) and a positive relationship on fungicide-treated trees of Desirable in 2010 (model $F$ value probability $=0.1, R^{2}=0.65$ ). Linear regres- sion analysis of the relationship between scab severity on fruit valves and sample height in August and October showed reasonable to good function fit on all fungicide-treated trees in all experiments (model $F$ value probability $=0.0004-0.1, R^{2}=0.57-0.96$ ), except on Desirable in October 2010 (model $F$ value probability = $0.5, R^{2}=0.22$ ). There was no linear relationship between scab severity and sample height on fungicide-treated trees in any of the three experiments.

\section{Discussion}

In the absence of fungicide applications, the most severely scabbed fruit tended to be found in the lower and middle canopy of tall, scab-susceptible pecan trees, particularly on fruit in August
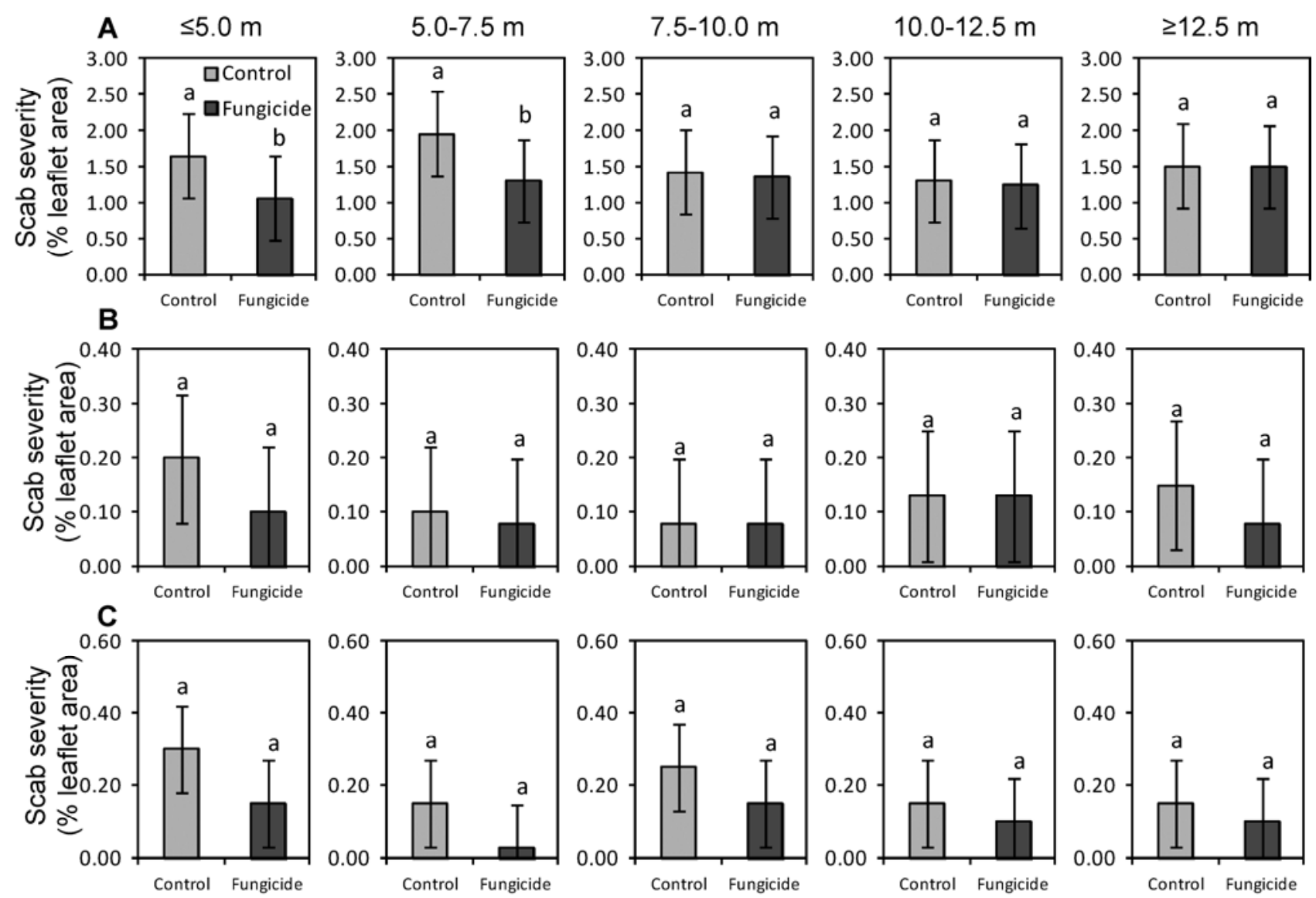

Fig. 5. Severity (\% area diseased per diseased leaflet) of pecan scab (Fusicladium effusum) on leaflets of pecan at different heights aboveground in the canopies of nontreated control trees and trees receiving fungicide applications using an air-blast sprayer. A, Cultivar Desirable, July 2010, B, cultivar Desirable, June 2011, and C, cultivar Wichita, June 2011, in Byron, GA. Data sliced by height ( $\mathrm{m}$ aboveground). If letters are different, then the severity of scab is significantly different between treatments according to t-grouping $(P=0.05) .95 \%$ confidence intervals are indicated.
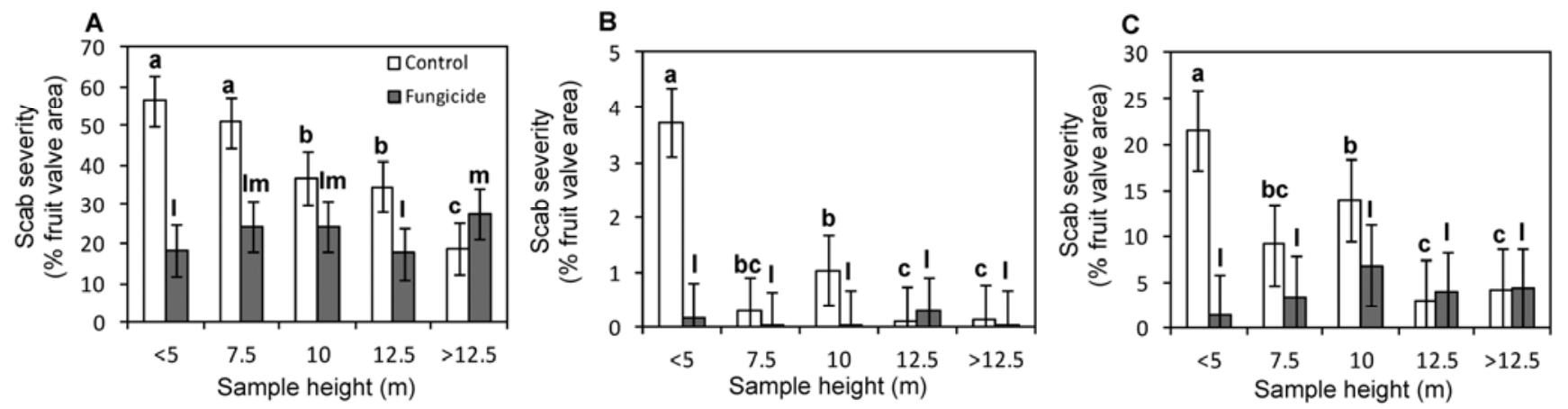

Fig. 6. Severity (\% area diseased per fruit valve) of pecan scab (Fusicladium effusum) on fruit at different heights aboveground in the canopy of nontreated control trees and trees receiving fungicide applications using an air-blast sprayer. A, Cultivar Desirable, August 2010, B, cultivar Desirable, August 2011, and C, cultivar Wichita, August 2011, in Byron, GA. Data sliced by treatment (nontreated or fungicide-treated). If letters are different within treatments, then the severity of scab is significantly different between heights according to t-grouping $(P=0.05)$. 95\% confidence intervals are indicated. 
and October. In contrast, fungicide-treated trees either had less severe scab low in the canopy or similar severity at all heights on both fruit and foliage. Reynolds (14) observed lesion counts were higher on twigs of both fungicide-treated and nontreated trees in the winter. Fungicide treatments could have a direct impact on the distribution of shoot lesions that overwinter and serve as a source of inoculum the following spring (14), and these shoot lesions could conceivably have an indirect impact on scab distribution on foliage and fruit the following season, but no indirect effect was observed in this study. Direct residual effects of fungicides from the previous season are unlikely (particularly after 9 months), and there was no evidence of more severe scab on the foliage or fruit in the upper canopy of nontreated trees. The nontreated trees of
Desirable and of Wichita sampled in 2010 and 2011, respectively, had been treated with fungicide during the year prior to the experiment (the nontreated trees of Desirable in 2011 received no fungicide for two seasons). Additional in-depth studies are needed to relate observations on shoots in winter (14) to those on the foliage and fruit.

Fungicide-treated trees either had less severe scab low in the canopy or similar severity at all heights on both fruit and foliage. The tracer experiment provided data that demonstrated little active ingredient reached heights $>10.0 \mathrm{~m}$ (and was similar to background levels), confirming results of some previous studies $(13,24)$. Thus, scab high in the canopy was influenced least by fungicide treatments, and the fungicide applications most often appeared to re-
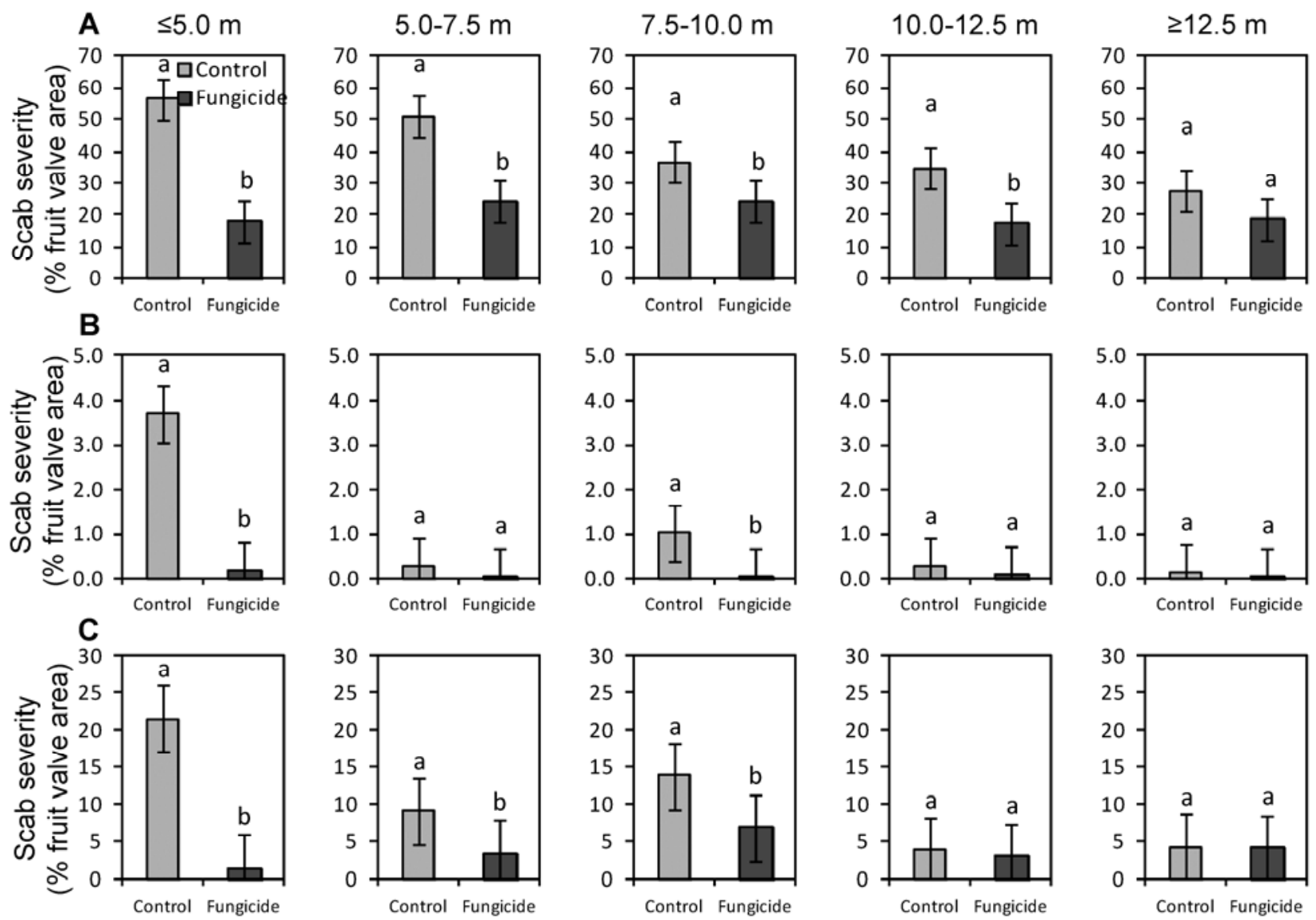

Fig. 7. Severity (\% area diseased per fruit valve) of pecan scab (Fusicladium effusum) on fruit at different heights aboveground in the canopy of nontreated control trees and trees receiving fungicide applications using an air-blast sprayer. A, Cultivar Desirable, August 2010, B, cultivar Desirable, August 2011, and C, cultivar Wichita, August 2011, in Byron, GA. Data sliced by height ( $\mathrm{m}$ aboveground). If letters are different, then the severity of scab is significantly different between treatments according to $t$-grouping $(P=$ 0.05). $95 \%$ confidence intervals are indicated.
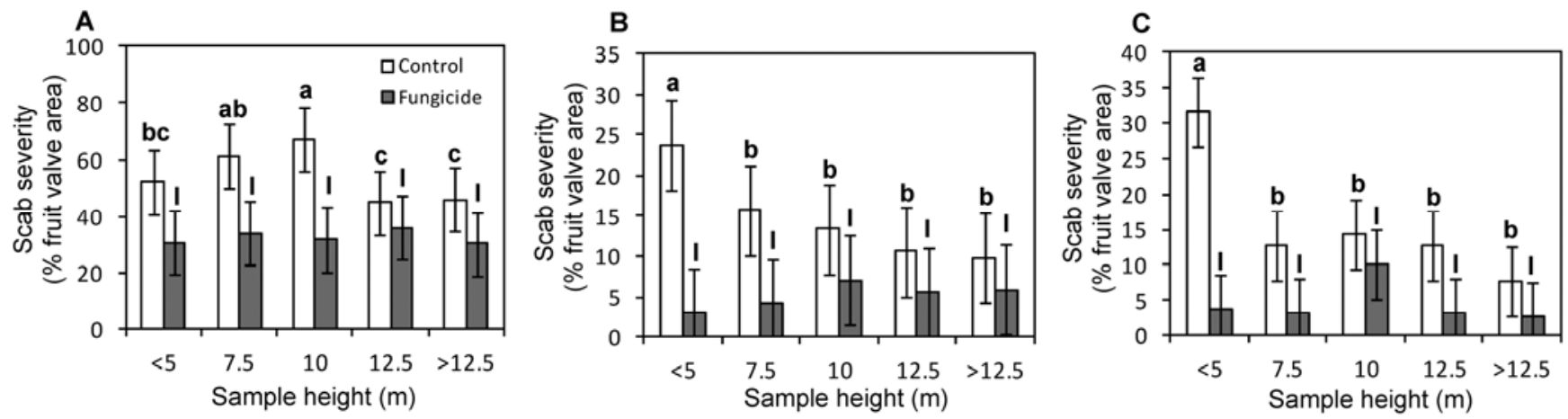

Fig. 8. Severity (\% area diseased per fruit valve) of pecan scab (Fusicladium effusum) on fruit at different heights aboveground in the canopy of nontreated control trees and trees receiving fungicide applications using an air-blast sprayer. A, Cultivar Desirable, October 2010, B, cultivar Desirable, October 2011, and C, cultivar Wichita, October 2011, in Byron, GA. Data sliced by treatment (nontreated or fungicide-treated). If letters are different within treatments, then the severity of scab is significantly different between heights according to t-grouping $(P=0.05) .95 \%$ confidence intervals are indicated. 
duce scab in the lower canopy to approximately the same severity as seen in the upper canopy of both treated and nontreated trees (Figs. 5, 7, and 9). This likely has ramifications for the development of fungicide resistance in $F$. effusum $(9,18,21)$, as the pathogen will be exposed to a gradient of active ingredient, which can frustrate attempts to manage fungicides to reduce the risk of fungicide resistance.

Despite low scab severity on foliage and some variability, the reduction in disease severity was observed to a height of $10 \mathrm{~m}$ on both foliage and immature fruit samples in August (shown by the percent reduction in scab on fungicide-treated versus nontreated trees, Fig. 10). At heights $>10 \mathrm{~m}$, the reduction in disease was inconsistent, and occasionally there was more scab on trees $\geq 10 \mathrm{~m}$, showing the waning effect of fungicide with greater canopy height.
However, in the October fruit samples, there was a consistent reduction of scab severity on fruit at all heights on fungicidetreated trees. Most likely this change in the efficacious effects of fungicide at heights $\geq 10 \mathrm{~m}$ in the tree canopy at least 2 months after the last fungicide application is due to the epidemic advancing throughout the canopies of untreated trees unchecked and at a greater rate compared to the fungicide-treated trees, resulting in the nontreated trees being substantially more severely scabbed at all heights in the canopy by the end of the season. Timing of fungicides is crucial to minimize disease, and in this study, although every effort was made to ensure appropriate timing, the first fungicide spray in both seasons was applied after leaf expansion was underway, so infection of foliage may well have occurred before the first fungicide spray was applied. Indeed, the foliar scab sever-

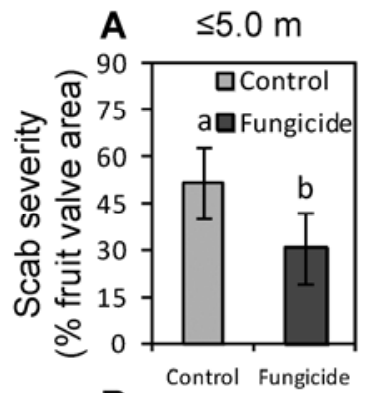

B

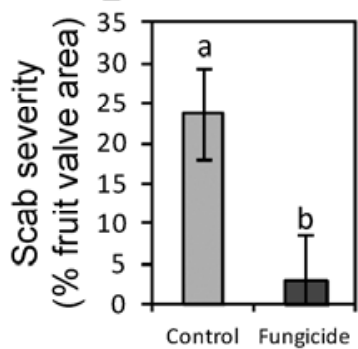

C

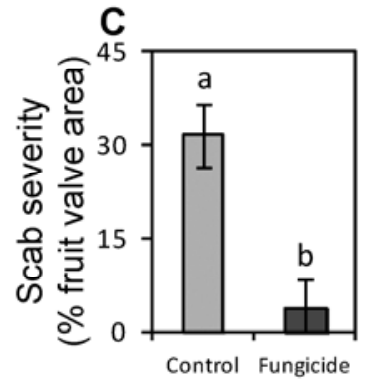

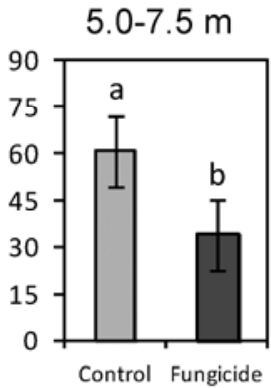
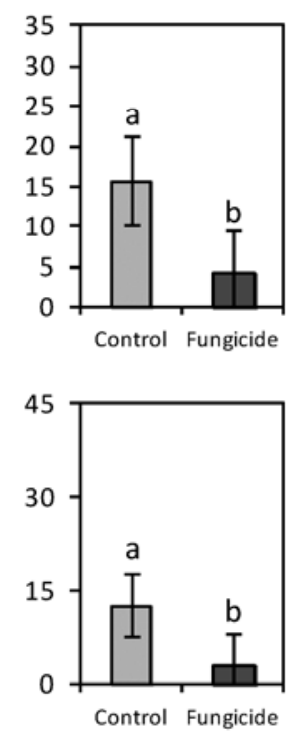

7.5-10.0 m
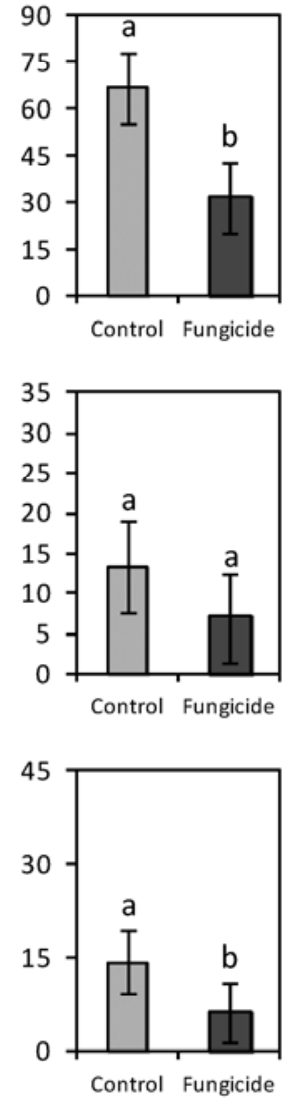
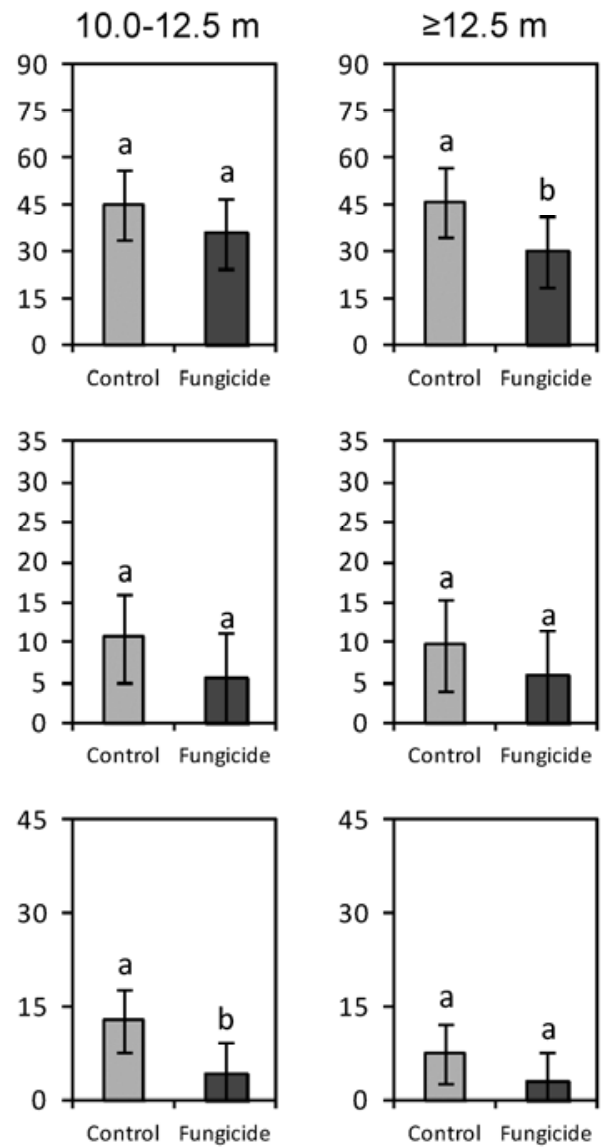

Fig. 9. Severity (\% area diseased per fruit valve) of pecan scab (Fusicladium effusum) on fruit at different heights aboveground in the canopy of nontreated control trees and trees receiving fungicide applications using an air-blast sprayer. A, Cultivar Desirable, October 2010, B, cultivar Desirable, October 2011, and C, cultivar Wichita, October 2011, in Byron, GA. Data sliced by height ( $\mathrm{m}$ aboveground). If letters are different, then the severity of scab is significantly different between treatments according to tgrouping $(P=0.05) .95 \%$ confidence intervals are indicated.
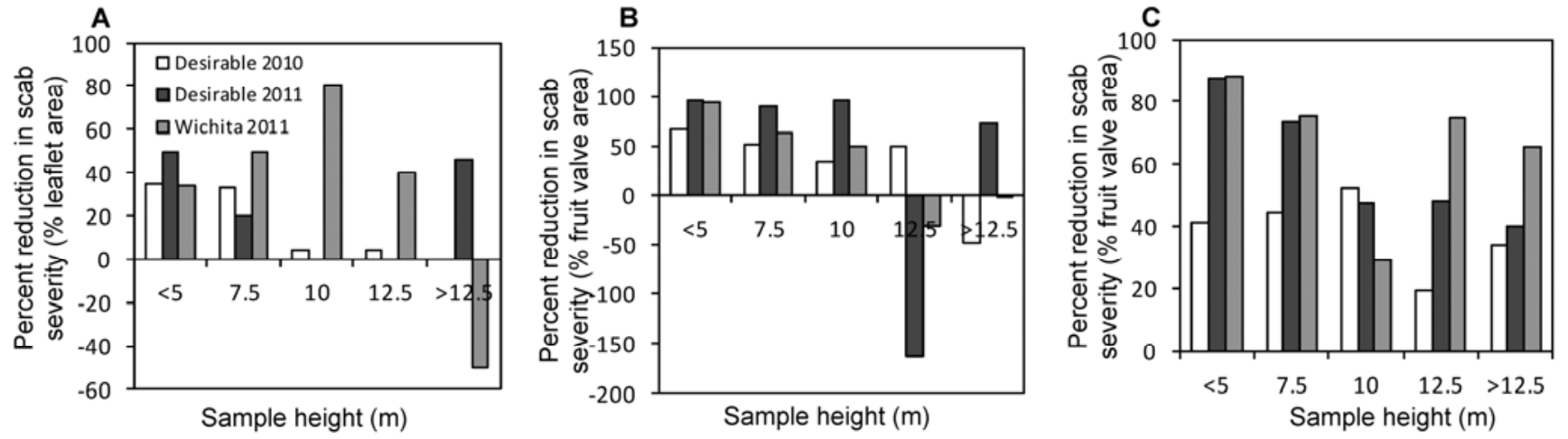

Fig. 10. Percent reduction ([severity on nontreated trees] - [severity on treated trees]/[severity on nontreated trees] $\times 100$ ) in scab severity at different heights in pecan canopies due to fungicide treatments at different times of the year on cultivar Desirable in 2010 and 2011, and on cultivar Wichita in 2011, in Byron, GA. A, Reduction in severity of scab on leaflets in June, B, reduction in severity of scab on fruit valves in August, and C, reduction in severity of scab on fruit valves in October. 
ity data suggest that at least some of the scab may have developed while trees were unprotected. Subsequent sprays to control scab on fruit were most often appropriately timed, but weather conditions occasionally precluded application, providing an opportunity for infection of the fungicide-treated trees.

In nontreated trees, there was a negative linear relationship between scab severity on fruit in August and October and canopy height. But there was virtually no relationship between scab severity and sample height in fungicide-treated trees, and where weak associations were found these were positive relationships, suggesting more severe scab in the upper canopy. More research is needed to fully characterize the relationships between scab severity and sample height in the tree canopy (which may be curvilinear), but these observations provide the first reported evidence of such a relationship.

The pathogen, F. effusum, is both wind and splash dispersed $(4,6,7)$, and although the spatio-temporal development of epidemics in the canopy has not been studied, it is quite likely that there is some disease aggregation identifiable during the epidemic due to point sources of inoculum, such as on old shucks or twig lesions from the previous season $(3,14,20)$. Furthermore, sources of inoculum for infection in the canopy have not been fully characterized (it is not known whether most scab in a canopy is due to alloinfection or autoinfection), and this could influence distribution of scab in the canopy. Typically, splash will fall under gravity in a canopy, so lower leaflets and fruit might be expected to intercept more inoculum as it is splashed down through the canopy from sources of spores above, leading to a gradient in scab severity. Environmental conditions in the lower parts of the canopy are likely to be more conducive to infection (more prolonged leaf wetness) compared to the upper portion of the canopy, further accentuating disease severity differences. However, this has not been established in pecan trees, and further work investigating spore dispersal, infection, and environmental conditions in the canopy is required.

Knowledge of the distribution of scab in pecan canopies is important in understanding the epidemiology of the pathogen, the sources of inoculum, and for an informed approach to disease management practice $(3,20)$. The results demonstrate that in nonfungicide-treated pecan trees, there is a tendency for scab severity to be greater in the lower canopy, and that on trees receiving fungicide from ground-based sprayers, efficacious control of scab is most evident low in the canopy, at least in mild to moderate epidemic years (13). However, in seasons (or locations) particularly conducive to severe scab, aerial applications of fungicide might be warranted (13), as the distribution and severity of scab in the upper canopy in such seasons is unknown and could be severe. Further studies applying a range of different application strategies, including ground-based and aerial combinations of fungicide sprays, are needed to gauge efficacy and the value of these options for more effectively managing scab in pecan orchards comprised of tall trees under a range of environmental conditions.

\section{Acknowledgments}

We are grateful to Emma Cutchens, Keith Hough, Shad Stormant, Bridget Rawls, and Stephanie de Vos for assisting with sampling and disease assessments, and to the Georgia Agriculture Commodity Commission for Pecans for providing grant funding toward this project.

\section{Literature Cited}

1. Bock, C. H., Brenneman, T. B., Hotchkiss, M. W., and Wood, B. W. 2012. Evaluation of a phosphite fungicide to control pecan scab in the southeastern USA. Crop Prot. 36:58-64.

2. Demaree, J. B. 1924. Pecan scab with special reference to sources of the early spring infections. J. Agric. Res. 38:321-333.

3. Everhart, S. E., Askew, A., Seymour, L., Holb, I. J., and Scherm, H. 2011. Characterization of three-dimensional spatial aggregation and association patterns of brown rot symptoms within intensively mapped sour cherry trees. Ann. Bot. 108:1195-1202.

4. Gottwald, T. R. 1982. Spore discharge by the pecan scab pathogen Cladosporium caryigenum. Phytopathology 72:1193-1197.

5. Gottwald, T. R. 1985. Influence of temperature, leaf wetness period, leaf age, and spore concentration on infection of pecan leaves by conidia of Cladosporium caryigenum. Phytopathology 75:190-194.

6. Gottwald, T. R., and Bertrand, P. F. 1982. Patterns of diurnal and seasonal airborne spore concentrations of Fusicladium effusum and its impact on a pecan scab epidemic. Phytopathology 72:330-335.

7. Gottwald, T. R., and Bertrand, P. F. 1983. Effect of time of inoculation with Cladosporium caryigenum on pecan scab development and nut quality. Phytopathology 73:714-718.

8. Gottwald, T. R., and Bertrand, P. F. 1988. Effects of an abbreviated pecan disease control program on pecan scab disease increase and crop yield. Plant Dis. 72:27-32.

9. Isakeit, T. 2009. Pecan scab: Understanding fungicide activity to prevent fungicide resistance. http://pecan.ipmpipe.org/library/content/pecan_scab MH\%20edited_management1.pdf

10. Lan, Z., and Scherm, H. 2003. Moisture sources in relation to conidial dissemination and infection by Cladosporium carpophilum within peach canopies. Phytopathology 93:1581-1586.

11. Latham, A. J. 1979. Some factors influencing pecan scab development. Highlights of the Agriculture Experiment Station of Auburn University, Spring 1979, Auburn. 26:7.

12. Latham, A. J. 1982. Effects of some weather factors and Fusicladium effususm conidium dispersal on pecan scab occurrence. Phytopathology 72:1339-1345.

13. Reilly, C. C., Wood, B. W., Cottrell, T. E., Sumner, P., Wells, L., and

Table 2. Linear regression ${ }^{\mathrm{a}}$ analysis of the relationships between severity (\% leaflet area or $\%$ fruit valve area diseased) of pecan scab (caused by Fusicladium effusum) and sample height in trees of cv. Desirable in 2010 and 2011, and cv. Wichita in 2011 in orchards at Byron, GA

\begin{tabular}{|c|c|c|c|c|c|c|c|}
\hline Treatment & Cultivar & Date of disease assessment ${ }^{b}$ & $\mathbf{M S}^{\mathbf{c}}$ & $F(P \text { value })^{d}$ & $a$ & $b$ & $R^{2 \mathrm{e}}$ \\
\hline \multirow[t]{9}{*}{ Nontreated } & \multirow[t]{6}{*}{ Desirable } & July 2010 & 0.1 & $1.6(0.3)$ & 1.85 & -0.09 & 0.34 \\
\hline & & August 2010 & 848 & $65(0.004)$ & 67.1 & -9.21 & 0.96 \\
\hline & & October 2010 & 83 & $0.8(0.5)$ & 63.0 & -2.88 & 0.22 \\
\hline & & June 2011 & $<0.01$ & $0.2(0.7)$ & 0.15 & -0.01 & 0.06 \\
\hline & & August 2011 & 5.4 & $4.0(0.1)$ & 3.26 & -0.73 & 0.57 \\
\hline & & October 2011 & 109 & $19(0.02)$ & 24.6 & -3.31 & 0.86 \\
\hline & \multirow[t]{3}{*}{ Wichita } & June 2011 & 0.03 & $7.1(0.08)$ & 0.40 & -0.06 & 0.70 \\
\hline & & August 2011 & 168 & $7.7(0.07)$ & 22.6 & -4.09 & 0.72 \\
\hline & & October 2011 & 231 & $6.4(0.09)$ & 30.3 & -4.81 & 0.68 \\
\hline \multirow[t]{9}{*}{ Fungicide-treated } & \multirow[t]{6}{*}{ Desirable } & July 2010 & 0.1 & $5.5(0.1)$ & 1.06 & 0.08 & 0.65 \\
\hline & & August 2010 & 14 & $0.7(0.5)$ & 18.8 & 1.19 & 0.19 \\
\hline & & October 2010 & 0.3 & $0.04(0.9)$ & 32.0 & 0.17 & 0.01 \\
\hline & & June 2011 & 0 & $0(1.0)$ & 0.09 & 0 & 0.00 \\
\hline & & August 2011 & 3.8 & $1.0(0.4)$ & 2.17 & 0.62 & 0.26 \\
\hline & & October 2011 & 0.02 & $0.01(0.9)$ & 4.21 & -0.04 & $<0.01$ \\
\hline & \multirow[t]{3}{*}{ Wichita } & June 2011 & $<0.01$ & $0.4(0.6)$ & 0.19 & -0.02 & 0.13 \\
\hline & & August 2011 & $<0.01$ & $0(1.0)$ & 0.12 & $>-0.01$ & $<0.01$ \\
\hline & & October 2011 & 5.3 & $3.2(0.2)$ & 2.94 & 0.73 & 0.51 \\
\hline
\end{tabular}

a Linear regression function, $y=a+b x(a=$ intercept, $b=$ slope $)$.

b June or July represent leaflet samples and August and October represent fruit samples.

${ }^{\mathrm{c}} \mathrm{MS}=$ means square .

${ }^{\mathrm{d}} F=F$-distribution value that tests goodness-of-fit for the model. $P=$ Probability the $F$ value is significant.

${ }^{\mathrm{e}} R^{2}=$ coefficient of determination (proportion of variability accounted for by $X$ ). 
Funderburk, F. 2007. Comparison of ground and aerial application, fungicide deposition and biological activity in large pecan trees. Pages 115-122 in: Proc. Southeastern Pecan Growers Assoc., 100th Annu. Convention, Marriot Bay Point Resort, Panama City Beach, FL.

14. Reynolds, K. L. 1995. Distribution and sporulation of overwintered scab lesions on pecan shoots. In: Sustaining Pecan Productivity into the 21st Century: 2nd National Pecan Workshop Proc. M. W. Smith, W. Reid, and B. W. Wood, eds. U.S. Dep. Agric., Agric. Res. Serv., 1995-3.

15. Reynolds, K. L., Brenneman, T. B., and Betrand, P. F. 1997. Sensitivity of Cladosporium caryigenum to propiconazole and fenbuconazole. Plant Dis. 81:163-166.

16. Sanderlin, R. S. 1995. Effect of nut scab on pecan yield and quality components. Pages 45-49 in: Sustaining Pecan Productivity into the 21st Century: 2nd National Pecan Workshop Proc. U.S. Dep. Agric., Agric. Res. Serv., 1995-3.

17. Scherm, H., Savelle, A. T., Boozer, R. T., and Foshee, W. G. 2008. Seasonal dynamics of conidial production potential of Fusicladium carpophilum in southeastern peach orchards. Plant Dis. 92:47-50.

18. Seyran, M., Brenneman, T. B., and Stevenson, K. L. 2010. A rapid method to detect fungicide sensitivity in the pecan scab pathogen, Fusicladium effusum. Crop Prot. 29:1257-1263.

19. Sparks, D., Yates, I. E., Bertrand, P. F., and Brenneman, T. B. 2009. The relative importance of elevation and rainy days on the incidence of scab damage of pecan nuts in the southeastern USA. J. Hortic. Sci. Biotech. 84:137-142.

20. Spósito, M. B., Amorim, L., Bassanezi, R. B., Filho, A. B., and Hau, B. 2008. Spatial pattern of black spot incidence within citrus trees related to disease severity and pathogen dispersal. Plant Pathol. 57:103-108.

21. Stevenson, K. L. 1999. Fungicide resistance management in pecans. Pages 58-64 in: 92nd Proc. Southeastern Pecan Growers Assoc.

22. Stevenson, K. L., and Bertrand, P. F. 2001. Within-season dynamics of yield loss due to pecan scab fruit infections. (Abstr.) Phytopathology 91:S85.

23. Stevenson, K. L., Bertrand, P. F., and Brenneman, T. B. 2004. Evidence for reduced sensitivity to propiconazole in the pecan scab fungus in Georgia. (Abstr.) Phytopathology 94:S99.

24. Sumner, P. E. 2004. Experiences with Pecan Air Blast Sprayers. 2004 American Society of Agricultural Engineers/Canadian Society of Agricultural Engineers Annual International Meeting.

25. Turechek, W. W., and Stevenson, K. L. 1998. Effects of host resistance, temperature, leaf wetness, and leaf age on infection and lesion development of pecan scab. Phytopathology 88:1294-1301.

26. Yadav, N. V. S., de Vos, S. M., Bock, C. H., and Wood, B. W. Development and validation of standard area diagrams to aid assessment of pecan scab symptoms on fruit. Plant Pathol. In press. 